УДК 343.1

DOI https://doi.org/10.32837/pyuv.v1i4(29).420

\author{
С.С. Кудінов \\ orcid.org/0000-0002-0582-1030 \\ доктор юридичних наук, \\ доцент кафедри кримінального права та процесу \\ Національної академії Служби безпеки України \\ О. В. Бачинський \\ orcid.org/0000-0002-0248-6142 \\ аспірант відділу аспірантури і докторантури \\ Національної академії Служби безпеки України
}

\title{
ПРАВОВЕ РЕГУ ЛЮВАННЯ ВИКОНАННЯ СПЕЦІАЛЬНОГО ЗАВДАННЯ З РОЗКРИТТЯ ЗЛОЧИННОЇ ДІЯЛЬНОСТІ ОРГАНІЗОВАНОЇ ГРУПИ ЧИ ЗЛОЧИННОЇ ОРГАНІЗАЦІЇ
}

Постановка проблеми. Одним із важливих результатів реформування системи кримінальної юстиції в Україні є вдосконалення нормативно-правового регулювання досудового розслідування кримінальних правопорушень, озброєння правоохоронних органів сучасними інструментами його здійснення й намагання вдосконалити організаційні та правові засади кримінального переслідування відповідно до передової іноземної практики. Реалізація зазначеного відбувалася шляхом втілення прогресивного світового досвіду організації протидії протиправній діяльності у кримінальному процесуальному законодавстві України, що, зокрема, знайшло свій прояв у детальній правовій регламентації провадження як гласних, так і негласних слідчих (розшукових) дій (далі - НСРД). Водночас вказана реформа впливає не тільки на зміст чинного Кримінального процесуального кодексу України (далі - КПК України), a й загалом докорінно змінює засади розслідування злочинів. Одним із важливих інструментів такої діяльності є саме виконання спеціального завдання з розкриття злочинної діяльності організованої групи чи злочинної організації (далі виконання спеціального завдання), що входить до системи НСРД, загальні засади організації якої регламентуються ст. 272 КПК України. Водночас можливість якісного й успішного його проведення нерозривно пов'язана з досконалим правовим регулюванням, що потребує відповідного наукового супроводження.

Аналіз останніх досліджень i публікацій. Виконання спеціального завдання в сучасному науковому просторі розглядається як важливий інструмент протидії організованій злочинності. Варто зазначити, що в більшості наукових досліджень, об'єктом яких було обрано виконання спеціального завдання, вказаний захід вивчали як явище теорії та практики оперативно-розшукової діяльності. Водночас 3 ухваленням у 2012 р. КПК України виконання спеціального завдання було включено до гл. 21 «Негласні слідчі (розшукові) дії, що активізувало наукову спільноту до розгляду вказаного явища як категорії кримінального процесу. Зокрема, виконання спеціального завдання предметом наукових досліджень обрали такі вчені: С.В. Албул, М.Ю. Азаров, М.В. Багрій, Л.В. Бобрицький, Г.М. Бірюков, А.А. Венедіктов, Є.Є. Гречин, В.І. Василинчук, А.А. Галючек, Л.Ф. Гула, С.О. Гриненко, О.М. Дроздов, Я.Ю. Конюшенко, С.С. Кудінов, В.В. Луцик, Н.Я. Маньковський, Ю.В. Мантуляк, М.А. Погорецький, П.П. Підюков, О.О. Сухачов, С.А. Хімченко, Р.М. Шехавцов та інші. Проте, незважаючи на значний внесок науковців у дослідження вказаної тематики, потреба ґрунтовного вивчення правового регулювання виконання спеціального завдання все ще $\epsilon$.

Мета статті полягає в аналізі стану правового регулювання виконання спеціального завдання 3 розкриття злочинної діяльності організованої групи чи злочинної організації, виокремленні проблемних питань та формулюванні пропозицій з їх розв'язання.

Виклад основного матеріалу. У науковій літературі існують різні погляди на визначення правового регулювання, проте більшість сучасних учених дотримуються широкого його розуміння. Відповідно до цього підходу, правове регулювання розглядають як специфічну діяльність держави, її органів і посадових осіб з упорядкування суспільних відносин шляхом встановлення правових норм, що визначають межі дозволеної поведінки, й ухвалення відповідно до них індивідуально регламентуючих рішень 3 юридично значущих питань, які виникають під час таких відносин. Особливості правового регулювання залежать від сфери регламентованих суспільних відносин, проте воно завжди має функціональну, управлінську сутність [1, с. 261].

Ретроспективний аналіз розвитку правового регулювання виконання спеціального завдання дозволяє зробити висновок, що зазначений інститут, до ухвалення у 2012 р. КПК України 
належить до системи оперативно-розшукових заходів. Сучасні реалії теорії та практики протидії організованій злочинності свідчать про те, що виконання спеціального завдання можна здійснювати відповідно до ст. 272 КПК України, а також п. 8 ч. 1 ст. 8 Закону «Про оперативно-розшукову діяльність», що передбачає право уповноважених оперативних підрозділів проводити виконання спеціального завдання у процесі здійснення оперативно-розшукової діяльності згідно з положеннями ст. 272 КПК України [2; 3]. Зазначене свідчить про те, що виконання спеціального завдання має подвійну правову природу та може мати різні мету, підстави та специфіку проведення, залежно від того, на виконання мети кримінального судочинства чи оперативно-розшукової діяльності його здійснюють.

Для аналізу правового регулювання доцільно застосовувати вертикальну (ієрархічну) систему законодавства, основним критерієм побудови якої $€$ юридична сила нормативно-правових актів. Традиційно в теорії держави та права така система виглядає так: 1) Конституція України - Основний закон, що має найвищу юридичну силу; 2) міжнародні договори України, згода на обов'язковість яких надана Верховною Радою України, які є частиною національного законодавства; 3) закони України (кодифіковані та некодифіковані); 4) підзаконні нормативно-правові акти (укази Президента України; постанови Кабінету Міністрів України; підзаконні нормативно-правові акти центральних органів виконавчої влади й інших центральних органів державної влади; нормативно-правові акти місцевих органів виконавчої влади; нормативно-правові акти органів місцевого самоврядування).

Основою правового регулювання в державі $€$ Конституція України, що становить базис для діяльності всіх державних органів, зокрема й із правоохоронними функціями. Конституція України встановлює основу правового регулювання і для виконання спеціального завдання, визначаючи засади конституційного статусу особи в державі, функціонування системи законодавчих, виконавчих і судових органів державної влади. Відповідність вимогам, закріпленим в Основному законі, $€$ беззаперечною під час проведення всіх без винятку НСРД, є першочерговим критерієм оцінки їхньої законності, а також допустимості отриманих під час їх проведення доказів. Крім того, Конституція як акт найвищої юридичної сили визначає базові цінності, основи та напрями подальшого розвитку законодавства, що регулює правоохоронну діяльність.

Вагоме значення у правовому регулюванні сьогодні мають міжнародні акти, ратифіковані Україною, адже вони відображають прогресивні спрямування міжнародної спільноти й задають вектори позитивного розвитку національного законодавства. Попри те, що вони передбачають загальні питання співробітництва у сфері кримінальної юстиції, окремі з них мають значення в розрізі правового регулювання виконання спеціального завдання та закріплюють базові положення щодо боротьби з незаконним обігом наркотиків i психотропних речовин (Конвенція Організації Об’єднаних Націй (далі - ООН) про боротьбу з незаконним обігом наркотиків і психотропних речовин, ратифікована Законом України від 24 квітня 1991 р. № 1000-XII), транснаціональною злочинністю (Конвенція ООН проти транснаціональної організованої злочинності ратифікована Законом України від 4 лютого 2004 р. № 1433-IV), корупцією (Конвенція ООН проти корупції, ратифікована Законом України від 18 жовтня 2006 р. № 251-V) тощо. Крім того, попри вживання різної термінології, необхідно зазначити, що цими актами надається можливість проведення дій, аналогічних виконанню спеціального завдання: агентурних операцій (ч. 1 ст. 20 Конвенції ООН проти транснаціональної організованої злочинності), таємних операцій (ч. 1 ст. 50 Конвенція ООН проти корупції) під час боротьби з відповідними видами злочинів. Водночас аналіз змісту вказаних актів свідчить, що міжнародні конвенції не обмежуються можливістю проведення таких заходів тільки щодо організованої злочинності, що є аргументом на користь можливого розширення сфери застосування виконання спеціального завдання.

Особливе місце серед актів, які регулюють виконання спеціального завдання, належить КПК України, адже саме з його ухваленням у 2012 р. поняття «виконання спеціального завдання з розкриття злочинної діяльності організованої групи чи злочинної організації» було введене до правозастосовної практики правоохоронних органів та наукового простору України. Гл. 21 КПК України визначає загальні положення проведення всіх НСРД, серед яких і виконання спеціального завдання. Так, у ст. 272 КПК України розкрито сутність виконання спеціального завдання, юридичні підстави, строки. Проте порядок проведення виконання спеціального завдання фактично залишився поза увагою національного законодавця.

Розглядаючи правове регулювання виконання спеціального завдання, потрібно також згадати Кримінальний кодекс України (далі - КК України), що закріплює базові категорії, які використовують під час проведення НСРД. Так, визначаючи підстави для проведення виконання спеціального завдання, необхідно оперувати такими поняттями, як: «класифікація злочинів за тяжкістю» (ст. 12 КК України), адже НСРД, передбачені ст. 272 КПК України, можна проводити виключно у кримінальних провадженнях щодо тяжкого 
й особливо тяжкого злочину; співучасті та визначення злочинів, які вважаються вчиненими організованою групою або ж злочинною організацією, адже тільки у кримінальних провадженнях щодо таких злочинних об'єднань може застосовуватись ст. 272 КПК України. Крім того, КК України визначає низку важливих положень, які формують основу статусу особи, що виконує спеціальне завдання, а саме ст. 43, яка відносить виконання спеціального завдання до обставин, що виключають злочинність діяння.

Необхідність деталізувати наявне на законодавчому рівні правове регулювання виконання спеціального завдання була реалізована завдяки ухваленню відповідного міжвідомчого нормативно-правового акта, яким сьогодні є Міжвідомча інструкція про організацію проведення негласних слідчих (розшукових) дій та використання їх результатів у кримінальному провадженні від 16 листопада 2012 р. № 114/1042/516/1199/936/1687/5. Однак аналіз змісту вказаної інструкції свідчить про те, що вона не вирішує вищезазначеної проблеми, а лише доповнює положення ст. 272 КПК України в частині визначення способу реалізації виконання спеціального завдання шляхом організації слідчим і оперативним підрозділом уведення особи, яка відповідно до закону виконує таке завдання, в організовану групу чи злочинну організацію [4].

Потреба захисту державного суверенітету, конституційного ладу й територіальної цілісності України, нейтралізації сепаратистських і екстремістських рухів і організацій, гарантування державної безпеки у сферах боротьби з тероризмом, економічної, інформаційної, кібернетичної безпеки гостро ставить питання про необхідність ефективного реагування правоохоронних органів і спеціальних служб із використанням адекватного інструментарію. Сьогодні в Україні на часі питання протидії не тільки організованій злочинності, а й іншим тяжким і особливо тяжким злочинам, які становлять реальну чи потенційну загрозу національній безпеці, життю та здоров'ю великої кількості людей. Однак проведення виконання спеціального завдання можливе тільки у кримінальних провадженнях стосовно організованих груп і злочинних організацій, незважаючи на те, що багато злочинів можуть бути вчинені або окремими особами, або таким чином, що унеможливлює виявлення ознак організованої злочинної діяльності.

Тому, на нашу думку, одним із найбільш суттєвих недоліків правового регулювання виконання спеціального завдання є закріплення в назві та змісті ст. 272 КПК України можливості проведення вказаної НСРД виключно у провадженнях стосовно організованих груп і злочинних організацій, що не є виправданим, адже позбавляє мож- ливості попереджувати, розкривати та припиняти окремі кримінальні правопорушення, які, хоч і не вчиняються організованими групами чи злочинними організаціями, є не менш небезпечними.

Очевидно, що в сучасних суспільно-правових умовах необхідно враховувати й інші критерії протиправного діяння для оцінки можливості використання виконання спеціального завдання у протидії злочинам. Тому сфера застосування ст. 272 КПК України потребує розширення, зокрема завдяки уникненню обмеження щодо організованих груп і злочинних організацій, i закріплення можливості проведення виконання спеціального завдання щодо інших кримінальних правопорушень, які також потребують ефективних заходів протидії. Зокрема, це стосується злочинів проти основ національної безпеки України, а також окремих інших злочинів (наприклад ст. 258 «Терористичний акт», ст. 258-5 «Фінансування тероризму» та ін.). Навіть більше, як показує практика, непоодинокі випадки вчинення зазначених вище діянь однією особою або у спосіб, який виключає встановлення наявності організованої групи чи злочинної організації, з використанням сучасних засобів зв'язку та новітніх технологій, для приховування зв'язків між зловмисниками. У таких випадках часто може бути доцільність виконання спеціального завдання, проведення якого, однак, не відповідатиме встановленим вимогам чинного законодавства через відсутність організованої групи чи злочинної організації або через неможливість встановлення необхідних фактів, що підтверджують їх існування.

Крім того, вказані у ст. 272 КПК України обмеження щодо проведення виконання спеціального завдання виключно щодо злочинної діяльності організованих груп та злочинних організацій під час розгляду виконання спеціального завдання як оперативно-розшукового заходу суперечать таким ознакам названих суб'єктів, як стійкість і здійснення злочинної діяльності систематично, на постійній основі. Виходячи з наявності ст. $255 \mathrm{KK}$ України - «Створення злочинної організації» та ïi змісту, необхідно констатувати, що виявлення злочинної організації фактично нівелює можливість проведення виконання спеціального завдання як оперативно-розшукового заходу, тому що такі факти підлягають невідкладному направленню до органу досудового розслідування для початку кримінального провадження, що передбачено у ст. 7 Закону України «Про оперативно-розшукову діяльність»: «У разі виявлення ознак злочину оперативний підрозділ зобов'язаний невідкладно направити зібрані матеріали, в яких зафіксовано фактичні дані про протиправні діяння окремих осіб та груп, відповідальність за які передбачена ККУ, до відповідного органу досудового розслідування» [3]. Крім того, наявність такої підстави для 
проведення виконання спеціального завдання, як учинення злочинної діяльності організованою групою чи злочинною організацією, вимагає обгрунтування наявності зазначеної структури, що створює схожі труднощі під час виявлення фактів скоєння злочинів відповідним суб'єктом. Ураховуючи, наприклад, дослідження В.М. Варцаби, відповідно до якого з усіх виявлених організованих структур тільки 6\% було викрито під час підготовки першого злочину (22\% після вчинення 2-3-х злочинів, $28 \%$ - 4-6-х злочинів; $12 \%-7-10$-ти злочинів, більше 10 злочинів - 8\%, більше 20 злочинів $6 \%$, один злочин - 18\%) [5], можна стверджувати, що фактично такий оперативно-розшуковий захід можна проводити виключно стосовно щойно створених злочинних груп, які тільки планують скоєння протиправних діянь. Зазначене значно обмежує можливості правоохоронних органів із виявлення протиправної діяльності, її припинення та протидії їй.

Схожі питання виникають і під час розгляду виконання спеціального завдання у площині контррозвідувальної діяльності (далі - КРД), метою якої є попередження, своєчасне виявлення і запобігання зовнішнім та внутрішнім загрозам безпеці України, припинення розвідувальних, терористичних та інших посягань спецслужб іноземних держав на державну безпеку [6]. Попри ускладненість реалізації виконання спеціального завдання з огляду на обмежену організованим групами та злочинними організаціями сферу застосування, існує надзвичайно актуальна потреба проведення зазначеного заходу і під час виконання завдань КРД. Уваги потребує проблематика визначення статусу спецслужб іноземних держав. Відповідно до приписів ст. 272 КПК України, виконання спеціального завдання можна проводити виключно щодо злочинної діяльності організованої групи чи злочинної організації. Водночас спеціальні служби іноземних держав є органами державної влади та не можуть бути визначені як організовані групи чи злочинні організації. I хоча протидія такій діяльності іноземних держав є одним з основних завдань національних спецслужб, вказані факти позбавляють можливості застосування передбачених у ст. 272 КПК України підстав для використання ними такого ефективного засобу протидії іноземним спецслужбам, як виконання спеціального завдання.

Водночас необхідно враховувати той факт, що КРД є спеціальним видом діяльності у сфері гарантування державної безпеки, який у демократичних країнах властивий спеціальним службам. Адже згідно з Резолюцією 1466 (2005) Парламентської Асамблеї Ради Європи «Про виконання обов’язків та зобов'язань Україною» та рекомендаціями ПАРЕ № 1713 (2005) «Про демократичний нагляд за положенням у сфері безпеки у країнах-членах"
[7; 8], протидія посяганням спецслужб іноземних держав на безпеку країни є повноваженням служб внутрішньої безпеки та реалізовується шляхом здійснення КРД. Водночас у зазначеному документі вказано, що, ураховуючи відмінності в завданнях та повноваженнях служб безпеки і розвідувальних служб, з одного боку, та правоохоронних органів з іншого, дуже важливо відобразити ці відмінності в законодавстві.Зважаючи на викладене, законодавче забезпечення КРД потребує вдосконалення в частині розробки системи відповідних контррозвідувальних заходів та її правової регламентації, які б забезпечували інтереси спецслужб та сприяли досягненню завдань КРД.

На нашу думку, для оцінювання стану правового регулювання виконання спеціального завдання в Україні доцільно також проаналізувати законодавство іноземних держав, яке унормовує проведення схожих за виконанням спеціального завдання заходів. У контексті цієї статті на особливу увагу заслуговує досвід правового регулювання окремих європейських країн у сфері застосування таких заходів.

Так, у кримінальному процесуальному кодексі Федеративної Республіки Німеччина (далі - ФРН) (§ 110а) здійснення відповідної діяльності можливе, якщо «існують достатні фактичні підстави для припущення, що вчиняються тяжкі злочини» у сфері незаконного обігу наркотиків чи зброї, підроблення платіжних заходів, у сфері охорони державної безпеки, або якщо вони вчиняються професійними злочинцями, членом банди чи в будь-який інший організований спосіб [13].

У Кримінальному процесуальному кодексі Франції аналогічному заходу присвячено цілий розділ «Інфільтрація», який передбачає можливість проведення відповідних заходів під час розслідування п'ятнадцяти видів злочинів, серед яких тероризм, торгівля людьми, торгівля наркотиками, вимагання й інші злочини, учинені в організованій формі (ст. 706-73) [14].

Досить широка сфера застосування вказаного заходу в Чехії. Так, Кримінальний процесуальний кодекс Чехії дозволяє проводити вказаний захід у кримінальних провадженнях щодо тяжких і особливо тяжких злочинів (у розумінні законодавства Чехіï) та щодо кримінальних правопорушень меншої тяжкості, зокрема у сфері банкрутства; порушення правил економічної конкуренції; віддання переваг під час здійснення державних контрактів, публічних закупівель і публічних аукціонів; корупції, підкупу, а також злочинів, учинених в організованій формі [15].

У Кримінальному процесуальному кодексі Швейцарії (ст. 286) до переліку злочинів, під час розслідування яких можуть проводитись відповідні заходи, віднесено приблизно п'ятдесят складів, серед яких злочини у сферах національної безпеки, 
обігу наркотиків і зброї, ядерної енергетики, лікарських засобів, ігрового бізнесу, а також участь у злочинній організації, фінансування тероризму, злочини проти миру та людства, корупційні злочини, відмивання грошей тощо [16].

Проаналізований іноземний досвід підтверджує, що виконання спеціального завдання є дієвим засобом протидії злочинності, проте сфера його застосування не обмежується наявністю виключно організованої злочинності.

Висновки. Отже, можна дійти висновку, що правове регулювання виконання спеціального завдання все ще є недосконалим, оскільки сфера його застосування обмежена виключно злочинами, учиненими організованими групами та злочинними організаціями. Це значно зменшує потенціал вказаного заходу, адже фактично унеможливлює його застосування щодо не менш небезпечних, але на даний момент особливо актуальних злочинів, наприклад, передбачених ст. ст. 109-113, 258, 258-3, 258-5 Кримінального кодексу України. У контексті зазначеного варто звернути увагу на іноземний досвід, який вказує на досить широку сферу застосування заходів, тотожних за змістом із виконанням спеціального завдання.

Уважаємо, що покращити правозастосовну практику виконання спеціального завдання та більшою мірою реалізувати потенціал зазначеного заходу як в оперативно-розшуковій діяльності, так і у кримінальному процесі можна за допомогою розширення сфери його застосування, не обмежуючись тільки злочинною діяльністю організованих груп та злочинних організацій. Тому одним із перших і найбільш важливих кроків з оптимізації правового регулювання виконання спеціального завдання повинна бути зміна назви ст. 272 КПК України та викладення іï в редакції: «Виконання завдання з розкриття злочинної діяльності», а також закріплення в її змісті нових, більш широких підстав для проведення, не обмежених поняттям «злочинна діяльність організованих груп та злочинних організацій» .

Крім того, ураховуючи актуальні загрози державній безпеці, необхідно активізувати наукову спільноту щодо опрацювання проблеми утворення та правового забезпечення системи контррозвідувальних заходів, до якої має увійти й виконання спеціального завдання, форма здійснення якого відповідала б потребам КРД.

\section{Iimepamypa}

1. Теорія держави і права : навчальний посібник / А.М. Колодій та ін. ; за заг. ред. С.Л. Лисенкова, В.В. Копєйчикова. Київ : Юрінком-Інтер, 2003. 368 с.

2. Кримінальний процесуальний кодекс України : Закон від 13 квітня 2012 р. № 4651-VI. Верховна Рада України : офіційний вебпортал. URL: http:// zakon.rada.gov.ua/laws/show/4651-17 (дата звернення: $30.10 .2019)$.
3. Про оперативно-розшукову діяльність : Закон України, від 18 лютого 1992 р. № 2135-XII. Верховна Рада Украӥни : офіційний вебпортал. URL: https:// zakon.rada.gov.ua/laws/show/2135-12 (дата звернення: 30.10.2019).

4. Про затвердження Інструкції про організацію проведення негласних слідчих (розшукових) дій та використання їх результатів у кримінальному провадженні : Наказ № 114/1042/516/1199/936/1687/5 від 16 лситопада 2012 р. Верховна Рада України : офіційний вебпортал. URL: http://zakon3.rada.gov.ua/ laws/show/v0114900-12 (дата звернення: 30.10.2019).

5. Варцаба В.М. Розслідування злочинів організованих злочинних груп (тактико-психологічні основи) : дис. ... канд. юрид. наук: 12.00.09. Харків, 2003. $188 \mathrm{c.}$

6. Про контррозвідувальну діяльність : Закон України від 26 грудня 2002 р. № 374-IV. Верховна Рада України : офіційний вебпортал. URL: https:// zakon.rada.gov.ua/laws/show/374-15 (дата звернення: 15.11.2019).

7. Про виконання обов'язків та зобов'язань Україною : резолюція 1466 (2005) Парламентської Асамблеї Ради Європи. URL: https://zakon.rada.gov.ua/rada/ show/ru/994_611 (дата звернення: 18.11.2019).

8. Про демократичний нагляд за положенням у сфері безпеки у країнах-членах : рекомендація ПАРЄ № 1713 (2005). URL: http://www. assembly.coe.int/nw/xml/XRef/Xref-XML2HTMLen.asp?fileid=17360\&lang=en (дата звернення 18.11.2019).

9. Кримінальний кодекс України : Закон України від 5 квітня 2001 р. № 2341-III. Верховна Рада України : офіційний вебпортал. URL: http://zakon2. rada.gov.ua/laws/show/2341-14 (дата звернення: 30.10.2019).

10. Конвенція ООН проти корупції, ратифікована Законом України від 18 жовтня 2006 р. № 251-V. Верховна Рада України : офіційний вебпортал. URL: https://zakon.rada.gov.ua/laws/show/995_c16 (дата звернення: 28.10.2019).

11. Конвенція ООН проти транснаціональної організованої злочинності, ратифікована Законом України від 4 лютого 2004 р. № 1433-IV. Верховна Рада України : офіційний вебпортал. URL: https://zakon.rada.gov. ua/laws/show/995_789 (дата звернення: 28.10.2019).

12. Конвенція ООН про боротьбу з незаконним обігом наркотиків і психотропних речовин, ратифікована Законом України від 24 квітня 1991 р. № 1000-XI. Верховна Рада Украӥни : офіційний вебпортал. URL: https://zakon.rada.gov.ua/laws/show/995_096 (дата звернення: 28.10.2019).

13. The German Code of Criminal Procedure St PO Full citation : Code of Criminal Procedure in the version published on 7 April 1987 (Federal Law Gazette [Bundesgesetzblatt]. Part I. P. 1074, 1319), as most recently amended by Article 3 of the Act of 23 April 2014 (Federal Law Gazette. Part I. P. 410) (English version). URL: https://www.gesetze-im-internet.de/englisch_ stpo/englisch_stpo.html (дата звернення: 18.11.2019).

14. Criminal procedure code of France (translated with the participation of John Rason SPENCER QC) (English version). URL: https://www.legislationline. org/documents/section/criminal-codes/country/30/ France/show (дата звернення: 19.11.2019).

15. Criminal Procedure Code of the Czech Republic (1961, amended 2012) (English version). URL: https:// www.legislationline.org/download/id/6371/file/ Czech\%20Republic_CPC_1961_am2012_en.pdf (дата звернення: 20.11.2019). 
16. Swiss Criminal Procedure Code of 5 October 2007 (Status as of 1 March 2019). (English version). URL: https://www.legislationline.org/download/id/8297/ file/Swiss_CPC_2007_am2019_en.pdf (дата звернення: 21.11.2019).

\section{Анотація}

Кудінов С. С., Бачинський О. В. Правове регулювання виконання спеціального завдання з розкриття злочинної діяльності організованої групи чи злочинної організації. - Стаття.

У статті проведено аналіз стану правового регулювання виконання спеціального завдання 3 розкриття злочинної діяльності організованої групи чи злочинної організації, виокремлено проблемні питання та подано пропозиції з їх розв'язання.

Авторами обгрунтовується необхідність ретельних досліджень у сфері правового регулювання виконання спеціального завдання. Це пов'язано зі значним впливом, який стан правового регулювання має на теоретичне забезпечення, а також практичну реалізацію виконання спеціального завдання. Однак правове регулювання виконання спеціального завдання сьогодні залишається недосконалим, значною мірою через те, що сфера його застосування обмежується виключно злочинами, учиненими організованими групами та злочинними організаціями. Такий підхід значно звужує потенціал цієї негласної слідчої (розшукової) дії, адже фактично унеможливлює її застосування щодо не менш небезпечних, на даний момент особливо актуальних злочинів. Тому у статті звертається увага на необхідність покращення практики виконання спеціального завдання шляхом розширення сфери його застосування, не обмежуючись тільки злочинною діяльністю організованих груп та злочинних організацій.

Зокрема, одним із перших і найбільш важливих кроків з оптимізації правового регулювання виконання спеціального завдання повинна бути зміна назви статті 272 Кримінального процесуального кодексу України та викладення іï в редакції: «Виконання завдання з розкриття злочинної діяльності», а також закріплення в її змісті нових, більш широких підстав для проведення, не обмежених поняттям «злочинна діяльність організованих груп та злочинних організацій».

Крім того, зазначається, що, ураховуючи актуальні загрози державній безпеці, необхідно активізувати наукову спільноту щодо опрацювання проблеми утворення та правового забезпечення системи контррозвідувальних заходів, до якої має увійти й виконання спеціального завдання, форма здійснення якого відповідала б потребам контррозвідувальної діяльності.

Ключові слова: правове регулювання, негласні слідчі (розшукові) дії, виконання спеціального завдання $з$ розкриття злочинної діяльності організованої групи чи злочинної організації.

\section{Summary}

Kudinov S. S., Bachynskyi O. $V$. The legal regulation of carrying out special assignment to expose criminal activities of the organized group or criminal organization. - Article.

The article is devoted to the study of the legal regulation of carrying out special assignment to expose criminal activities of the organized group or criminal organization. Carrying out special assignment is attributed to the covert investigative (detective) actions, during which evidence is obtained or verified in criminal proceedings concerning the activities of an organized group or criminal organization as one of the most dangerous manifestations of crime.

This article shows that the need for a thorough study of the legal regulation of carrying out the special assignment still exists. That is also because of the huge impact which the legal regulation of carrying out special assignment has on the theoretical basis as well as its practical implementation. However, the legal regulation of carrying out special assignment nowadays is still imperfect, since its scope is limited solely to the crimes committed by organized groups and criminal organizations. This significantly diminishes the potential of this covert investigative (detective) action. Such approach makes it impossible to apply carrying out special assignment to other equally dangerous and relevant crimes. The article describes how to improve law enforcement practices by expanding the scope of carrying out special assignments application.

Therefore, the change in the formulation of Article 272 of the CPC of Ukraine for the following: "Carrying out special assignment to expose criminal activities" is required. As well as definition in its content new broader grounds for conducting (not limited to the concept of "criminal activity of organized groups and criminal organizations") is also necessary. The article alludes to the benefit of taking into consideration the foreign experience of legal regulation of similar activities

Besides, given the current threats to national security, it is necessary to step up the scientific community to address the problem of the creation and legal support of a system of counterintelligence measures, which should include carrying out special assignment, the form of implementation of which would meet the needs of the counterintelligence practice.

Key words: legal regulation, carrying out special assignment to expose criminal activities of organized group or criminal organization. 